\title{
Business Innovation and Competitive Advantage in Nigerian Manufacturing Sector
}

\section{Moruff Sanjo Oladimeji}

Olabisi Onabanjo University, Nigeria | moruff.oladimeji@ oouagoiwoye.edu.ng

\section{Olasunkanmi Akeem Amida}

Olabisi Onabanjo University, Nigeria | sunkanmi.amida@gmail.com

\section{Ekong Akpan Essien}

Olabisi Onabanjo University, Nigeria | essien.ekong@ oouagoiwoye.edu.ng

Volume 9 No 2 (2019) ｜ ISSN 2158-8708 (online) | DOI 10.5195/emaj.2019.188 | http://emaj.pitt.edu |

\section{Abstract}

The study examined the impact of business innovation on competitive advantage in the Nigerian Manufacturing Sector. The study was anchored on the theory of the resource-based theory and the dynamic capabilities theory. The descriptive survey design was employed. The population for the study comprised 496 staff of Nestle Nigeria Plc, Ogun State. A sample size of 217 respondents was selected through stratified sampling and a simple random sampling procedure. The questionnaire was administered to the respondents, out of which 207 were retrieved and subjected to further analysis. The stated hypotheses were tested using ordinal regression. The results showed that business innovation has a significant effect on the cost of the product $\left(\mathrm{R}^{2}=0.729, \mathrm{~F}=11.237 ; \mathrm{p}<.05\right)$, the sales of the product $\left(\mathrm{R}^{2}=0.643, \mathrm{~F}=3.408 ; \mathrm{p}<.05\right)$ and the quality of the product $\left(\mathrm{R}=0.845, \mathrm{R}^{2}=0.714, \mathrm{~F}=10.903 ; \mathrm{p}<.05\right)$. The study recommended that multinational companies should pay more attention to customer satisfaction by increasing product quality. Emphasis should also be placed on innovation in order to cut a competitive edge.

Keywords: Business Innovation, Quality, Product, Competitive Advantage, Manufacturing Sector

\section{$(\mathrm{Cc}) \mathrm{EY}$}

New articles in this journal are licensed under a Creative Commons Attribution 3.0 United States License.

\section{ULIS D-Sente}

This journal is published by the University Library System of the University of Pittsburgh as part

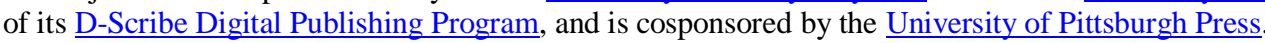




\section{Business Innovation and Competitive Advantage in Nigerian Manufacturing Sector}

\author{
Moruff Sanjo Oladimeji \\ Olasunkanmi Akeem Amida \\ Ekong Akpan Essien
}

\section{Introduction}

Businesses in the twenty-first century, irrespective of their sizes, are an integral part of the global community in which activities affect and are being influenced by events' social change and decisions from around the world. This is so because of the dynamic business environment characterized by discontinuous and highly competitive activities. In recent times, a radical change has been observed in the relationship between society and business organizations. The major drivers of this change are increased influence and size of organizations, globalization of trade, change in style of government, and the increase in the knowledge of the importance of stakeholders, most notably the customers (Matsa, 2009).

The competitive business environment has created complexity and sophistication in the business decision-making process, which requires strategic management. Managing various and multi-faceted internal activities is only part of the modern executive's responsibilities. The firm's immediate external environment poses another set of challenges. In order to effectively cope with the challenges that affect the ability of a company to grow profitably, top management design processes that are capable of facilitating the optimal positioning of the firm are significant. The strategic processes allow more accurate anticipation of environmental changes and improved preparedness for reacting to unexpected internal and competitive demands.

Innovation is a mental process that leads to the creation of a new phenomenon; this phenomenon may be new material, new services, or new techniques.
Innovation is the integration of vital components or ideas which lead to creating new thinking and concepts that were not previously available (Kao, 2011). Innovation is seen as a pivotal factor that stimulates value creation and sustains firms' competitiveness in today's highly dynamic and complex environment (Ranjit, 2004). Firms respond to changes by constantly creating new capabilities, which helps them to optimize resources and achieve better performance (Montes, Moreno \& Fernandez, 2004). According to Tellis, Prabhu, and Chandy (2009), innovation is a tool that managers can employ in creating and sustaining competitive advantage. Innovation can be viewed from the perspectives of product innovation, changes in the product a firm makes, the service offered by the firm, and process innovation. (Tushman and Nadler, 2010).

Porter (1985) argues that, competitive advantage grows out of the value a firm is capable of creating for its buyers that exceed the firm's cost of creating it. Customers are willing to pay for value, and superior value is created when firms offer the best prices compared to their competitors. Competitiveness is a tool for sustained performance, which should be treated as a dependent variable (Anthony \& Shapiro, 2002). Clark, Hayes, and Wheelwright (2008) posit that organizations compete in the marketplace by virtue of possessing one or more competitive priorities such as flexibility, lower cost, quality, and time.

Various scholars have shown that technological innovation could create positive impacts and improve the competitiveness of a firm (Evans, 1993; Bernard, 2001; Forster, 2006). However, to the best of the researchers' knowledge, there is skewness in literature as it relates to the extent to which innovation influences competitiveness and the need for a greater understanding of the most significant measure of innovation affecting firms' competitiveness. There is a need to address the paucity of innovation as it affects firms' competitiveness in developing countries such as Nigeria and particularly in the manufacturing sector. It is against this background that this study tends to examine business innovation and competitive advantage in Nigerian Manufacturing Sector with emphasis on the following specific objectives: 
examine the effect of business innovation on the cost of the product, determine the effect of business innovation on sales of the product, ascertain the effect of business innovation on quality of the product.

This study aims at finding the answer to certain questions which include:

i. What is the effect of business innovation on the cost of the product?

ii. What is the effect of business innovation on sales of the product?

iii. What is the effect of business innovation on the quality of the product?

\section{Literature Review}

Innovation was a term first coined at the beginning of the 20th century by Schumpeter (1934). According to Schumpeter, innovation does not originate from scientific recovery, but can be seen in process, product, and changes in organizational activities. Zizlavsky (2011) is of the opinion that, innovation may arise from the integrating of already existing technologies and their application in a new context. Innovation could also be gained from research and development. (Bernard, 2001). Therefore, innovation can be seen as not been limited to technical and technological improvement but also in the practical application of knowledge, which particularly originates from human capital and creative research work. Zemplinerova (2010) suggests that research and development, and human capital are important determinants of innovation.

The concept of competitive advantage evolved from the classical theory of comparative advantage postulated by David Ricardo, which has its primary focus on primary production assets. Porter (1985) established the concept of a competitive advantage that focuses on cost leadership and differentiation in the product. However, Treacy and Wiersema (1995) established a generic framework for achieving competitive advantage.

They opine that competitive advantage is gained through customer intimacy, operational excellence, and product leadership. Competition has also emerged between traditional commercial banks and other financial institutions. The development and globalization of financial markets have intensified the need for modifying the current structure and condition of the financial system.

Porter (1985) opined that competitiveness of an organization has become the source of success in the market and that value adding strategies in the value chain and resource capabilities in a firm's internal environment account for its core competencies which can invariably lead to competitive advantage. This according to Porter (1985) can arise from the following sources:
i) Differentiation strategy
ii) Low cost strategy
iii) Capability
iv) Positive reputation
v) Learning Organization

Competitive advantage dimensions according Evans (1993), Crosby (1995), Knoll and Jarvenpaa (1994), Forster (2006) includes: i) Time ii) Quality iii) Cost iv) Flexibility. These dimensions according to them play a significant role in determining the competitive advantages of one firm over the others.

Various studies have looked into how businesses can create and sustain competitive advantage Barney (1991) lists four (4) essential requirements for a resource or skill to be a source of sustainable competitive advantage. According to Barney (1991), for resources or skills to constitute a source of sustainable competitive advantage, they must possess the following characteristics; they must be valuable, they must be rare among a firm's current and potential competitors, they must be imperfectly imitable, and finally, there must not be any strategically equivalent substitutes for the resource or skill.

Business innovation is when an organization introduces new processes, services, or products to affect positive change in their business. Business innovation can be explicitly seen as the adoption of new behavior or ideas by an organization that has the capacity to facilitate 
better performance. Damanpour (1996) is of the view that innovation can be seen from the perspective of new technologies, modified processes, new products or services, evolving organizational structures or systems and creation to new programs which can facilitate better performance in employees. It could also be noticed that the following factors can be of assistance when making innovation as part of strategies: i) Choose your goals, ii) Build processes iii) Measure systematically iv) Put the right tools in place.

Chuang (2005) opined that organizational innovation can be divided into two distinctive types: i) technical or technological innovation; and ii) administrative innovation. It was also observed that Innovation offers companies the following benefits: i) Getting ahead of potential disruption ii) Increased efficiency iii) Talent attraction and retention iv) Brand perception

The following type of business innovation were also identified: i)Product innovation ii) Process innovation iii) Business model innovation iv) Delivery innovation. These types of business innovation gave rise to a more efficient, forward-thinking, and led to greater profitable. It also led to practical steps to jump-start innovation, thereby leading to renovation of offices, internal innovation programs implementations and execution of new ideas.

The linkage between innovation and competition has been of importance to various scholars (Schmutzler, 2013). Changing structures and potential competitors have been seen as critical factors influencing research and development. Firms that engaging in research and development to improve innovation and increase competitiveness are few due to the cost of such research (Gilbert, 2006). Porter (1985) proposes a competitive strategy comprising a two-part process. The first process consists of deciding on the product-market scope of the company, which includes the services and product that the organization will provide and the market segments in which they will be provided. The second process involves devising a competitive strategy relating to achieving a competitive advantage.

The Dynamic Capabilities theory updates the resource-based theory. This theory emphasizes the integration, protection, and deployment of a firm's competences and resources (Teece, 1997). Organizational processes and tools are the determinants of the dynamic capabilities of a firm that are embedded in the organization's resources, and the unique paths the organization adopts and inherits.

The dynamic capabilities theory establishes that, firms should best use their resources based on the current market dynamics and evolving business environment. That is, as the business environment evolves, the internal resources must be employed and optimized in relation to the evolving business environment. The different resources (tangible and intangible) at the disposal of the firm determines how the firm reacts to changes (Collis, 1991). Douglas and Craig (1989) posit that firms should take proactive steps to expand their operations through innovation.

The resource-based theory of the firm is very useful when dealing with competitiveness among firms. The competitive advantage and organization performance is determined by its unique capabilities (Johnson, Scholes and Whittington, 2008). Wernerfelt (1984); Rumelt (1984); Penrose (1959); and Wernerfelt (1995) observed that, the resource-based view (RBV) as a basis for the competitive advantage of a firm lies basically on the application of the available resources be it tangible or intangible.

The key to a resources based approach to strategy formulation understands the relationships between resources, capabilities, competitive advantage and performance. According to Barney (1999), RBV explained that a firm's sustainable competitive advantage is reached by virtue of unique resources being rare, valuable, inimitable, non-tradable, and non-substitutable, as well as firm specific. Resource based approach to sustainable competitive advantage focuses on the internal analysis of a firm. A firm's strengths are its resources and capabilities that can be used as a basis for developing a competitive advantage which can either be tangible or intangible. 


\section{Methodology}

The survey research design was employed in this study. The adoption of this type of research design involves the use of the questionnaire, which was used in eliciting information for this study. Furthermore, the questionnaires were designed in such a way that the questions asked would provide useful answers to the research questions as well as test the hypotheses of the study.

The targeted population of this study consists of four hundred and ninety-six (496) items. The sample size for this research work was determined using Krejice and Morgan (1970) sample size determinant table. The total population is within the range of 500 , and therefore two hundred and seventeen (217) was used as sample size as recommended Krejice and Morgan (1970).

Table 1: Table for determining Sample Size of a

\section{Known Population}

\begin{tabular}{|c|c|c|c|c|c|c|c|c|c|}
\hline $\mathrm{N}$ & $\mathrm{S}$ & $\mathrm{N}$ & $\mathrm{S}$ & $\mathrm{N}$ & $\mathrm{S}$ & $\mathrm{N}$ & $\mathrm{S}$ & $\mathrm{N}$ & $\mathrm{S}$ \\
\hline 10 & 10 & 100 & 80 & 280 & 162 & 800 & 260 & 2800 & 338 \\
\hline 15 & 14 & 110 & 86 & 290 & 165 & 850 & 265 & 3000 & 341 \\
\hline 20 & 19 & 120 & 92 & 300 & 169 & 900 & 269 & 3500 & 346 \\
\hline 25 & 24 & 130 & 97 & 320 & 175 & 950 & 274 & 4000 & 351 \\
\hline 30 & 28 & 140 & 103 & 340 & 181 & 1000 & 278 & 4500 & 354 \\
\hline 35 & 32 & 150 & 108 & 360 & 186 & 1100 & 285 & 5000 & 357 \\
\hline 40 & 36 & 160 & 113 & 380 & 191 & 1200 & 291 & 6000 & 361 \\
\hline 45 & 40 & 170 & 118 & 400 & 196 & 1300 & 297 & 7000 & 364 \\
\hline 50 & 44 & 180 & 123 & 420 & 201 & 1400 & 302 & 3000 & 367 \\
\hline 55 & 48 & 190 & 127 & 440 & 205 & 1500 & 306 & 9000 & 368 \\
\hline 60 & 52 & 200 & 132 & 460 & 210 & 1600 & 310 & 10000 & 370 \\
\hline 65 & 56 & 210 & 136 & 480 & 214 & 1700 & 313 & 15000 & 373 \\
\hline 70 & 59 & 220 & 140 & 500 & 217 & 1800 & 317 & 20000 & 377 \\
\hline 75 & 63 & 230 & 144 & 530 & 226 & 1900 & 320 & 30000 & 379 \\
\hline 80 & 66 & 240 & 148 & 600 & 234 & 2000 & 322 & 40000 & 380 \\
\hline 85 & 70 & 250 & 152 & 650 & 242 & 2200 & 327 & 50000 & 381 \\
\hline 90 & 73 & 260 & 155 & 700 & 248 & 2400 & 331 & 75000 & 382 \\
\hline 95 & 76 & 270 & 159 & 750 & 254 & 2600 & 335 & 1000000 & 384 \\
\hline
\end{tabular}

Source: Krejcie, R.V., \& Morgan, D.W. (1970). Determining Sample Size for Research Activities. Educational and Psychological Measurement, 30, 607610.

* N is Population Size, $\mathrm{S}$ is Sample Size

In order to representatively select the two hundred and seventeen (217) respondents, stratified random sampling and simple random technique were used.
The research instrument adopted is questionnaire. The questionnaire was divided into two sections. Section A and B. Section A of the questionnaire consisted of the demographic characteristics of the respondents, while section $\mathrm{B}$ of the questionnaire was centered on the impact of business innovation on competitive advantage in Nigerian Manufacturing Sector, which was designed based on the research objectives.

The face and content validity of the research instruments was established through the expert judgment in the Department of Business Administration, Olabisi Onabanjo University, Ogun State.

In order to establish the degree of reliability, consistency, stability, and accuracy of the instrument, Cronbach's alpha test measuring the credibility and consistency of the standard measures/scale was used. The reliability test result shows 0.75 co-efficient. This revealed that the research instrument measures accurately what it was designed to measure.

\section{Research Hypotheses}

Ho1: There is no significant effect of business innovation on the cost of the product

Ho2: Business innovation does not have a significant effect on the sales of the product

Ho3: Business innovation does not have a significant effect on the quality of the product

\section{Results and Discussion}

\section{Hypothesis One}

There is no significant effect of business innovation on the cost of the product.

Table 2: Summary of Hypothesis 1 Result

\begin{tabular}{llllll}
\hline \multicolumn{5}{l}{ Cost of Product } \\
\hline Variable & $\mathrm{B}$ & $\mathrm{SE}$ & $\mathrm{B}$ & T-stat & $\mathrm{P}$ \\
\hline Business Innovation & 0.332 & 0.112 & 0.311 & 2.757 & 0.000 \\
$\mathrm{R}^{2}$ & & 0.729 & & & \\
$\mathrm{~F}$ & & $11.237 * *$ & & \\
& & $(\mathrm{p}=0.000)$ & & \\
& & & \\
& & & & \\
& & & & & \\
& & & & & \\
\end{tabular}

Source: Authors' Computation 
The result reveals that, business innovation independently accounts for $72.9 \%$ of the variation in the cost of the product. $27.3 \%$ variation in the cost of the product is caused by other factors. The $\mathrm{t}$-value $(\mathrm{t}=2.757$, $\mathrm{p}=0.000$ ) reveals that, business innovation is a significant predictor of the cost of the product. The F-statistics $(\mathrm{F}=11.237, \mathrm{p}=0.000)$, the model, is significant in explaining the effect of business innovation on the cost of the product. Hence, it is established that business innovation has a significant effect on the cost of the product. The alternative hypothesis is accepted. The findings corroborate the submission of Oirere, (2015).

\section{Hypothesis Two}

Business innovation does not have a significant effect on the sales of the product.

Table 3: Summary of Hypothesis 2 Result

\begin{tabular}{llllll}
\hline \multicolumn{5}{l}{ Sales of Product } \\
Variable & $\mathrm{B}$ & $\mathrm{SE}$ & $\mathrm{B}$ & $\mathrm{T}$-stat & $\mathrm{P}$ \\
\hline Business Innovation & 0.502 & 0.081 & 0.496 & 6.124 & 0.000 \\
$\mathrm{R}^{2}$ & & 0.629 & & & \\
$\mathrm{~F}$ & & $3.408^{* *}$ & & \\
& & & \\
& & & \\
& & & & \\
\end{tabular}

Source: Authors' Computation

The result reveals the relationship between business innovation and sales of the product. This reveals that a $62.9 \%$ variation in sales of the product is determined by business innovation. $37.1 \%$ variation in sales of the product is determined by other factors. The standardized Beta $(\beta)$ reveals that, there is a direct relationship between business innovation and sales of the product. The $\beta$ shows the direction of the relationship to be strong at 0.496 . The $\mathrm{t}$-statistics value $(\mathrm{t}=6.124, \mathrm{p}=0.000)$ reveals that, the predictor is significant in explaining sales of the product. The F-statistics result reveal the value $\mathrm{F}=3.408 * *, \mathrm{p}=0.003$. This reveals that, business innovation is a significant and reliable model in explaining sales of the product. Therefore, the null hypothesis is rejected, and the alternative accepted. Thus, it is established that business innovation has a significant effect on sales of the product.

\section{Hypothesis Three}

Business innovation does not have a significant effect on the quality of the product.

Table 4: Summary of Hypothesis 3 Result

\begin{tabular}{llllll}
\hline \multicolumn{5}{c}{ Quality of the product } \\
\hline Variable & $\mathrm{B}$ & $\mathrm{SE}$ & $\mathrm{B}$ & $\mathrm{T}$-stat & $\mathrm{P}$ \\
\hline Business Innovation & 0.641 & 0.251 & 0.633 & 2.522 & 0.000 \\
$\mathrm{R}^{2}$ & & 0.701 & & & \\
$\mathrm{~F}$ & & $10.903^{* *}$ & & \\
& & $(\mathrm{p}=0.003)$ & & \\
& & & & \\
& & & & \\
\end{tabular}

Source: Author's Computation

The result reveals the relationship between the business innovation and the quality of the product. This reveals that a $70.1 \%$ variation in the quality of the product is determined by business innovation. $29.9 \%$ variation in the quality of the product is determined by other factors. The standardized Beta $(\beta)$ reveals that, there is a direct relationship between business innovation and sales of the product. The $\beta$ shows the direction of the relationship to be strong at 0.633 . The t-statistics value $(\mathrm{t}=2.522, \mathrm{p}=0.000)$ reveals that, business innovation is significant in explaining the quality of the product. The F-statistics result reveal the value $\mathrm{F}=10.903 * *, \mathrm{p}=0.003$. This reveals that, business innovation is a significant and reliable model in explaining the quality of the product. Therefore, the null hypothesis is rejected, and the alternative accepted. Thus, it is established that business innovation has a significant effect on the quality of the product.

\section{Discussion of Findings}

It was evident from the study conducted that, business innovation has a significant effect on the cost of the product. Business innovation has a significant effect on the sales of the product, and the study also revealed that, business innovation has a significant effect on the quality of the product. The submission of Oirere (2015) corroborated this finding, that innovation provides organizations with a means of adapting to the changing and competitive environment and often is critical for firm 
survival. Firms with greater innovativeness will be more successful in responding to competitiveness in business environments. The findings from this study conform with the view of McCarthy and Perreault (1999), which establish product innovation as a key driver of consistent patronage by existing and potential customers. These assertions were corroborated by Kotler (2004), who is of the opinion that to develop to keep customers coming, create and sustain competitiveness, an organization must create and deliver products that are of superior value at the best market price as perceived by the customers.

\section{Conclusion and Recommendations}

The study conducted shows clearly that, business innovation has a significant effect on competitive advantage in Nestle Nigeria Plc, Ogun State. Hence, Nestle Nigeria Plc, Ogun State, should, through consistent market survey, identify the needs and expectations of the existing and potential consumers, who are the live wires of any business, because, without consumers, their businesses will cease to exist. An organization's long term run is related to its ability to create new products/services and modify existing products in order to satisfy the customers. Organizations should endeavor to adopt product innovation and provide a favorable environment through encouraging research and development, providing financial sources to support new innovations, putting efficient programs and policies, and motivating innovators.

It is recommended that top management should invest in research and development, as this will stimulate innovation and better product offerings and in order to sustain competitive advantage, firms should focus on product innovation first before any other type of innovation.

Finally, as globalization grows and competition intensifies in developing economies, it is essential for multinational companies to understand local consumers' perceptions about their level of innovations and product development. Multinational companies should also be aware of the level of customer satisfaction derived from local products and also the level of customer loyalty.
Although managers may exert considerable effort, gaining accurate local marketing knowledge of the level of product development innovation, customer satisfaction, and loyalty level remain a huge challenge for any multinational in developing economies. Multinationals may increase their knowledge on the product development and innovation process, from the local level, and thus help by setting clear organizational goals.

\section{References}

Anthony, M.T., \& Shapiro, A. R. (2002). Product Development: Success through product and CycleTime Excellence, Stoneham, MA. ButterworthHeienhmann.

Barney J.B. (1991). Firm resources and sustained competitive advantage. Journal of Management: $17: 99-120$

Bernard, A.C. (2001). Science and knowledge flow: Evidence from the French case. Research Policy, 30(7), 1069-1078.http://dx.doi.org/10.1016/S00487333(00)00131-1

Clark K. B., Hayes R. H., and Wheelwright S. C. (2008). Dynamic Manufacturing. New York, NY: The Free Press.

Crosby, P. B. (1995). Philip Crosby's Reflections on Quality: 295 Inspirations from the World's Foremost Quality Guru. New York: McGraw-Hill.

Evans, J.R. (1993). Applied Production and Operations Management. West Publishing Co. The USA.

Forster, F. (2006). The Idea behind Business Process Improvement: Towards a Business Process Improvement Pattern Framework. BPTrends. http://www.bptrends.com. 
Johnson, J. L., \& Scholes A.O \& Whittington, W. (2008). Ideal and actual product adaptation in US exporting firms: Market-related determinants and impact on performance. International Marketing Review, 12(3), 31-46.

Kao, J. J. (2011). Entrepreneurship, Creativity, and Organization: Text, Cases and Readings, Prentice Hall, New Jersey.

Knoll, K., \&Jarvenpaa, S., L. (2014). Information Technology Alignment or "Fit" in Highly Turbulent Environments: the Concept of Flexibility. Paper presented at the Computer Personnel Research Conference on Reinventing. Alexandria, Virginia, USA.

Matsa, D. A. (2009).Competition and Product Quality in the Supermarket Industry. http://are.berkeley.edu/documents/seminar/matsacompetition- 090706.pdf

Montes, F. J., Moreno, A. R., Fernandez, L. M. (2004).Assessing the Organizational Climate and Contractual Relationship for Perceptions of Support for Innovation. International Journal Manpower, 25(2), 167-80.

Porter, M.E. (1985). Competitive Advantage. New York, NY: Free Press.

Ranjit, B. (2004). Knowledge Management Metrics.Industrial Management \& Data Systems, 104(6), 457-68.

Tellis, G.J., Prabhu, J.C., and Chandy, R.K. (2009). Radical innovation across nations: the preeminence of corporate culture. Journal of Marketing, 73(1), 3-23.

Tushman, M. \& Nadler, D. (2010). Organizing for innovation. California Management Review, 28(3), 74-92. http://dx.doi.org/10.2307/41165203
Zemplinerová, A. (2010). Inovačníaktivitafirem a konkurence.Politickáekonomie, 58(6)747-760. 